\section{Presence of illicit drugs and pharmaceutical residues in the wastewaters of an eastern Canadian city}

\author{
A. Palardy, ${ }^{1}$ J.-P. Gagné, ${ }^{1}$ L. Tremblay ${ }^{2}$ \\ 1 Institut des sciences de la mer de \\ Rimouski, Université du Québec à \\ Rimouski, Québec; 'Department of \\ Chemistry and Biochemistry, Université \\ de Moncton, Moncton, New Brunswick, \\ Canada
}

\section{Introduction}

According to the World Drug Report ${ }^{1}$ the prevalence of illicit drug (ID) consumption among the worldwide population aged 15-64 is between 162 and 324 million people. Moreover, billions of pharmaceutical pills are produced every year for medication use. The illicit and legal human consumption of these compounds, their excretion as metabolites or unchanged molecules and their transport through the sewer system lead to their presence in wastewaters. Wastewater treatment plants (WWTP) are inefficient to remove all ID, pharmaceuticals and their metabolites causing the dispersion of these compounds in effluents and in aquatic environments. In addition, sewage sludges (biosolids) produced by WWTP are often recycled as soil amendment. The possible leaching of ID and pharmaceuticals sorbed to biosolids can also disperse them in soils, rivers and ultimately in the ocean. Consumption of ID and pharmaceuticals are a modern global issue due to continuous supply of these compounds in many aquatic environments.

Data on ID occurrence are increasing worldwide. ${ }^{2}$ However, the data published on the presence of ID in wastewaters of Canadian municipalities is limited to three cities ${ }^{3,4}$ and almost nothing is known on the environmental fate of ID following wastewater treatments. Despite significant databases on the toxicological effects of ID and pharmaceuticals on humans, their deleterious effects and toxicity on freshwater and marine wildlife is limited. ${ }^{5,6}$

The analysis of raw urban sewage can be used to provide estimates of drug use, to determine temporal and spatial trends in drug use at different scales, and to identify changes in habits and the use of new substances. ${ }^{7,8}$ Moreover, the analysis of ID in different WWTP effluents could be a good indicator of the amount of ID introduce in aquatic environments. The wastewater analysis approach consists in two important steps. ${ }^{7}$ The first step is the quantification of target molecules in a rep- resentative sample (composite $24 \mathrm{~h}$ ). The second step is the estimation of different amounts of target residues by back-calculation. At the end, we obtain estimates of ID quantities entering the WWTP and amounts consumed by 1000 inhabitants providing societal key indicators at city or nationwide level. However, this approach cannot provide information on prevalence and frequency of use or the purity of the drugs consumed. ${ }^{7}$ The back-calculations require precise knowledge of the sewage flow, the metabolism of the target compounds, the proportion of the different metabolites rejected by the body, the bacterial degradation rates in WWTP, the proportion of the compound sorbed on activated sludge or suspended matter, etc. Knowledge on sorption of ID onto particles is a real limitation of wastewater analysis since very little data exist. The aim of this study was to measure the presence of six psychoactive substances (three ID and three pharmaceutical residues) in wastewaters from a Canadian city in the Maritime Provinces. We also studied the sorption of these compounds onto particles to quantify the interactions of these compounds with sediments or suspended matter.

\section{Materials and Methods}

\section{Sampling and analysis}

The studied ID were methamphetamine, benzoylecgonine, the main metabolite of cocaine, and 11-nor-9-carboxy- $\Delta^{9}$-tetrahydrocannabinol (THC-COOH), the main urinary metabolite of cannabis. Codeine, morphine and methadone were selected for pharmaceutical residues. High purity standard solutions and deuterated compounds (>97\%) were purchased from Cerilliant (Round Rock, TX, USA).

The wastewaters from a WWTP of a medium size Canadian city in the Maritime Provinces was sampled and processed. As recently suggested, ${ }^{9}$ the name of the city is not provided, but results are normalized to 1000 inhabitants to allow comparison. Twenty-four hours composite influent and effluent samples were collected on Saturday October $25^{\text {th }}$ and Monday October $27^{\text {th }} 2014$. This sampling allows comparing consumption on weekdays and weekends. The sampled WWTP uses an enhanced primary treatment. Samples were collected in clean one liter amber glass bottles. All samples were filtered through glass fiber filters (GF/D and $\mathrm{GF} / \mathrm{F}$, Whatman), acidified to $\mathrm{pH}=2$ and stored at $4^{\circ} \mathrm{C}$ until analysis. ${ }^{10}$ The extraction were done on $100 \mathrm{~mL}$ of influent and $200 \mathrm{~mL}$ of effluent. Samples were spiked with labeled compounds, at concentration of $100 \mathrm{ng} / \mathrm{L}$. Extraction were performed with Oasis HLB cartridges for THC-COOH following the procedure of Bijlsma et al. ${ }^{11}$ and other compounds were extracted with OASIS MCX cartridges
Correspondence: Jean-Pierre Gagné, Institut des sciences de la mer de Rimouski, Université du Québec à Rimouski, 310 allée des Ursulines, C.P. 3300, Rimouski, Québec, Canada, G5L 3A1.

Tel.: +1.418.723.1986 ext. 1870

Fax: +1.418.724.1842.

E-mail: jean-pierre_gagne@uqar.ca

Key words: Sewage biomarker analysis; sorption; illicit drugs; benzoylecgonine; methamphetamine; codeine; morphine; methadone; cannabis.

Acknowledgments: this work was supported by NSERC Discovery grant to Jean-Pierre Gagné. The authors are grateful to Secrétariat aux affaires intergouvernementales canadiennes $d u$ Québec for a grant to develop La coopération universitaire en matière d'enseignement supérieur et de recherche Québec - Nouveau-Brunswick and to Québec-0céan for its financial support.

Conference presentation: part of this paper was presented at ECOBIM meeting, 2015 May, Québec City, Québec, Canada.

This work is licensed under a Creative Commons Attribution NonCommercial 3.0 License (CC BYNC 3.0).

(C) Copyright A. Palardy et al., 2015

Licensee PAGEPress, Italy

Journal of Xenobiotics 2015; 5:5773

doi:10.4081/xeno.2015.5773

according to the method described in Baker $e t$ $a l .{ }^{12}$ After the extractions of compounds, the analyses were performed with an Accela LC system hyphenated to a LTQ FT Orbitrap mass spectrometer (Thermo Fisher Scientific, Waltham, MA, USA). The analytes were separated at $25^{\circ} \mathrm{C}$ on a Cortecs C18 column (150x3 $\mathrm{mm}, 2.7 \mathrm{~m}$, Waters) with a C18 guard column (Waters). A binary elution gradient was applied from $100 \%$ solvent A (formic acid $0.1 \%$ in water) to $100 \%$ solvent $B$ (formic acid $0.1 \%$ in methanol) in $23 \mathrm{~min}$, followed by an equilibration time of $5 \mathrm{~min}$. Mass spectrometer operating parameters are described elsewhere. ${ }^{11}$ Calibration curves (8 concentrations), assessment of recovery and matrix effects have been done with isotope labeled internal standards.

\section{Sorption assays}

The optimal soil/solution ratio, the kinetics of sorption and the losses during different steps were determined according to the batch equilibrium method. ${ }^{13,14}$ Briefly, glass bottles with Teflon screw caps were filled with $0.5 \mathrm{~g}$ of homogenized marine sediments, $50 \mathrm{~mL}$ of electrolyte solution $(0.01 \mathrm{M} \mathrm{CaCl})$, and a mixture of target compound at $2.0 \mathrm{ug} / \mathrm{L}$. These suspensions were shaken for $48 \mathrm{~h}$, then filtered through GF/F glass fiber filter and extracted as described above to obtain the concentrations 
Table 1. Concentrations of illicit drugs and drugs residues in influents and effluents and consumption by community.

\begin{tabular}{|c|c|c|c|c|c|c|}
\hline & \multicolumn{3}{|c|}{ Saturday } & \multicolumn{3}{|c|}{ Monday } \\
\hline & \multicolumn{2}{|c|}{ Influent } & \multirow{2}{*}{$\begin{array}{c}\text { Effluent } \\
\text { Concentration } \\
\text { ng/L }\end{array}$} & \multicolumn{2}{|c|}{ Influent } & \multirow{2}{*}{$\begin{array}{c}\text { Effluent } \\
\text { Concentration } \\
\text { ng/L }\end{array}$} \\
\hline & $\begin{array}{c}\text { Concentration } \\
\text { ng/L }\end{array}$ & $\begin{array}{c}\mathrm{mg} / \mathrm{day} / 1000 \\
\text { inhabitants }\end{array}$ & & $\begin{array}{c}\text { Concentration } \\
\text { ng/L }\end{array}$ & $\begin{array}{l}\mathrm{mg} / \mathrm{day} / 1000 \\
\text { inhabitants }\end{array}$ & \\
\hline \multicolumn{7}{|l|}{ Drug residues } \\
\hline Codeine & 285.6 & 279 & 71.4 & 263.4 & 257 & 64.0 \\
\hline Morphine & 121.4 & $-*$ & 44.9 & 116.7 & $-*$ & 43.2 \\
\hline Methadone & 25.1 & 53 & 7.5 & 27.8 & 59 & 9.2 \\
\hline \multicolumn{7}{|l|}{ Illicit drugs } \\
\hline Benzoylecgonine & 8.9 & 12 & 6.3 & $<\mathrm{LOD}$ & $-{ }^{\circ}$ & $<\mathrm{LOD}$ \\
\hline Methamphetamine & 6.8 & 9 & 5.7 & $<\mathrm{LOD}$ & $-{ }^{\circ}$ & $<\mathrm{LOD}$ \\
\hline THC-COOH & 12.5 & 53 & $<\mathrm{LOD}$ & 11.7 & 36 & $<\mathrm{LOD}$ \\
\hline
\end{tabular}

$<\mathrm{LOD}$, inferior to limit of detection; THC-COOH, 11-nor-9-carboxy- $\Delta^{9}$-tetrahydrocannabinol. *No estimation was done for morphine because this compounds could be issue from two sources, direct consumption and from metabolism of heroin; ${ }^{\circ}$ No estimation was done because $<$ LOD.

Table 2. Affinity of illicit drugs and drugs residues onto sediments estimated from distribution coefficient and carbon-normalized distribution coefficient.

\begin{tabular}{lcc} 
& $\mathbf{K}_{\mathbf{d}}$ & $\mathbf{K}_{0 c}$ \\
Drug residues & & \\
Codeine & 31 & 1028 \\
Morphine & 114 & 3773 \\
Methadone & 444 & 14793 \\
Illicit drugs & & \\
Benzoylecgonine & 3 & 97 \\
Methamphetamine & 42 & 1387 \\
THC-COOH & 1052 & 35077 \\
\hline
\end{tabular}

THC-COOH, 11-nor-9-carboxy- $\Delta^{9}$-tetrahydrocannabinol.

of dissolved compounds in the aqueous phase. The quantity of compounds sorbed onto sediment were estimated by subtracting the quantity of compounds dissolved in the aqueous phase to the initial quantity of compounds added to the sorption reactor at the beginning of the experiment. Correction for losses of analytes due to pre-concentration steps and sorption onto bottle walls and caps were calculated for each drugs. The sorption of compounds onto sediments was quantified by the distribution coefficient, $K_{d}$, and the organic carbon-normalized distribution coefficient, $\mathrm{K}_{\mathrm{oc} .}{ }^{13,14}$

\section{Results and Discussion}

\section{Concentration of illicit drugs and pharmaceutical residues in wastewater}

Table 1 shows the concentrations of ID and drug residues measured in influents and effluents of a WWTP of a Canadian city. Levels of ID in influents were from below the limit of detection (LOD), for benzoylecgonine and methamphetamine on Monday, to $12.5 \mathrm{ng} / \mathrm{L}$ for THC$\mathrm{COOH}$ on Saturday. In effluents, concentrations ranged from lower than LOD to $6.3 \mathrm{ng} / \mathrm{L}$ for benzoylecgonine on Saturday. THC-COOH, the metabolite of marijuana, was the dominant ID in wastewaters followed by benzoylecgonine, issue from cocaine, and then methamphetamine. The concentrations of THC- $\mathrm{COOH}$, benzoylecgonine and methamphetamine were generally lower than those reported for other Canadian cities. ${ }^{3,4}$ Concentrations were higher on Saturday than on Monday as well as for untreated influents compared to treated effluents (Table 1). THC-COOH was more efficiently removed by the WWTP (i.e., almost $100 \%$ removal) than benzoylecgonine or methamphetamine (16-29\% removal).

For pharmaceutical residues, levels were between $25.1 \mathrm{ng} / \mathrm{L}$ and $285.6 \mathrm{ng} / \mathrm{L}$ in influents and between $7.5 \mathrm{ng} / \mathrm{L}$ and $71.4 \mathrm{ng} / \mathrm{L}$ in effluents. Codeine was the preeminent pharmaceutical followed by morphine and methadone. There was no significant difference $(\mathrm{P}>0.05)$ between samples collected on Saturday and Monday. The concentrations measured in $24 \mathrm{~h}$ composite untreated wastewater samples were lower for codeine $(\sim 50 \%)$ or similar for methadone to levels reported for another Canadian city of comparable size. ${ }^{4}$ A comparison of the levels of pharmaceutical residues entering the WWTP and those in the effluents showed a removal of 63 to $75 \%$ for the three studied compounds.

\section{Community drug usage}

The ID concentrations measured in wastewater influents allowed estimating the ID consumption for weekday (Monday) and weekend (Saturday). Weekday cocaine and methamphetamine consumptions increased by 6 fold during the weekend. For instance, the estimates for cocaine were $12 \mathrm{mg} /$ day/1000 inhabitants in weekend, but $2 \mathrm{mg} /$ day/1000 inhabitants in weekday. Estimates of marijuana consumption showed a slight 1.5 fold increase for the same days. It thus appears that cocaine and methamphetamine consumption are mainly from recreational use during weekend while the consumption of marijuana appears more constant throughout the week. ${ }^{2,12,15}$ The population-normalized consumptions estimated in this studied city were lower than in bigger cities in Canada (12 mg/day/1000 inhabitants this study vs $1570 \mathrm{mg} / \mathrm{day} / 1000$ inhabitants) ${ }^{3}$ or in Europe. ${ }^{2}$ Our results confirm the main trend that cocaine consumption is higher in highly urbanized area. ${ }^{2,3}$ The estimation of use for methamphetamine $(9 \mathrm{mg} /$ day/1000 inhabitants for weekends) were similar to those found in London (England) or Milan (Italy) ${ }^{16}$ but lower than levels found in Scandinavian cities like Helsinki, Turku or Oslo ( 230-350 mg/day/1000 inhabitants from Figure 2 in Thomas et $\left.a l^{2}\right)$. Cannabis consumption ( $53 \mathrm{mg} /$ day/1000 inhabitants) measured in the present study was similar to values found in Spain. ${ }^{17}$

\section{Sorption of illicit drugs and phar- maceutical residues onto sediments}

We have evaluated the sorption coefficient for the six compounds. Preliminary works have shown that sorption kinetics reached a steady state after $48 \mathrm{~h}$ (data not shown). Table 2 shows the results obtained using $48 \mathrm{~h}$ of contact time between dissolved analytes and sediments. The distribution coefficients, $\mathrm{K}_{\mathrm{d}}$, greatly varied, between 3 to $1052 \mathrm{~mL} / \mathrm{g}$, depending on the compound. For $\mathrm{K}_{\mathrm{oc}}$, the values varied from about 100 to $35,000 \mathrm{~mL} / \mathrm{g}$. $\mathrm{K}_{\mathrm{d}}$ and $\mathrm{K}_{\mathrm{oc}}$ are 
proxies of the affinity of a compound for sediments or suspended particulate matter (SPM) and particulate organic matter, respectively. Following the classification of McCall et al., ${ }^{18}$ benzoylecgonine, due to its very low $\mathrm{K}_{\mathrm{oc}}$, has very little affinity for SPM and particulate organic matter. This compound should be observed mostly in the dissolved form and should be very mobile in aqueous media. In contrast, THC-COOH and methadone with their $\mathrm{K}_{\mathrm{oc}}>5000 \mathrm{~mL} / \mathrm{g}$ showed a high affinity for sediments and should be mostly bounded to SPM or sludge in WWTP and should not be very mobile. Methamphetamine, codeine and morphine showed intermediate affinity for SPM. Despite their high affinity for SPM, the detection of THC-COOH and methadone in effluents suggests that equilibrium sorption was not achieved during the transit of these molecules into the WWTP or that concentrations of SPM in WWTP were low so most of these compounds remained in water instead to be sorbed. Data from sorption experiments suggest that the community drug usage estimates could be accurate for benzoylecgonine but underestimated for the other compounds considering that a significant proportion of them should be sorbed onto solid particles present in WWTP. Our data suggest that sorption behaviors could significantly affect the presence of target compounds in wastewater and should be taken into account when estimating community drug usage.

\section{Conclusions}

Our study highlights the presence of low levels of drug residues and illicit drugs in wastewaters of a WWTP of a Canadian City in the Maritime Provinces. These compounds may interact with particles. THC-COOH showed the strongest affinity to particulate matter and could be partially removed by sorption in WWTP or could interact with sediments or SPM if it is released in the environment.

\section{References}

1. United Nations Office on Drugs and Crime (UNODC). World Drug Report 2014. New York: United Nations; 2014. Available from: https://www.unodc.org/documents/wdr201 4/World_Drug_Report_2014_web.pdf

2. Thomas TV, Bijlsma L, Castiglioni S, Covaci A, Emke E, Grabic E, et al. Comparing illicit drug use in 19 European cities through sewage analysis. Sci Total Environ 2012;432:432-9.

3. Metcalfe C, Tindale K, Li H, Rodayan A, Yargeau V. Illicit drugs in Canadian municipal wastewater and estimates of community drug use. Environ Pollut 2010;158:3179-85.

4. Yargeau V, Taylor B, Li H, Rodayan A, Metcalfe CD. Analysis of drugs of abuse in wastewater from two Canadian cities. Sci Total Environ 2014;487:763-70.

5. Rosi-Marshal EJ, Snow D, Bartelt-Hunt SL, Paspalof A, Tank JL. A review of ecological effects and environmental fate of illicit drugs in aquatic ecosystems. J Hazard Mat 2015;282:18-25.

6. Daughton CG, Ternes TA. Pharmaceuticals and personal care products in the environment: agents of subtle change. Env Health Perspect 1999;107:907-38.

7. Castiglioni S, Thomas KV, KasprzykHordern B, Vandam L, Griggiths P. Testing wastewater to detect illicit drugs: state of the art, potential and research needs. Sci Tot Environ 2014;483:613-20.

8. Zuccato E, Chiabrando C, Xastiglioni S, Bagnatti R, Fanelli R. Estimating cummunity drug abuse by wastewater analysis. Environ Health Perspect 2008;116:102732.

9. Prichard J, Hall W, de Voogt P, Zuccato E. 2014. Sewage epidemiology and illicit drug research: The development of ethical research guidelines. Sci Total Environ 2014;472:550-5.

10. Kankaanpää A, Ariniemi K, Heinonen M, Kuoppasalmi K, Gunnar T. Use of illicit stimulant drugs in Finland: A wastewater study in ten major cities. Sci Total Environ 2014;487:696-702.

11. Bijlsma L, Emke E, Hernández F, de Voogt
P. Performance of the linear ion trap Orbitrap mass analyzer for qualitative and quantitative analysis of drugs of abuse and relevant metabolites in sewage water. Anal Chim Acta 2013;768:102-10.

12. Baker DR, Barron L, Kasprzyk-Hordern B. Illicit and pharmaceutical drug consumption estimated via wastewater analysis. Part A: Chemical analysis and drug use estimates. Sci Total Environ 2014;487:62941.

13. Organisation for Economic Cooperation and Development (OECD). Test No. 106: Adsorption -- Desorption using a batch equilibrium method, OECD guidelines for the testing of chemicals, section 1. Paris: OECD Publishing; 2000. Availble from: http://www.keepeek.com/Digital-AssetManagement/oecd/environment/test-no106-adsorption-desorption-using-a-batchequilibrium-method_9789264069602en\#page1

14. Soubaneh YD, Lebeuf M, Gouteux B, Xie H, Nikiforov V, Gagné JP. Investigations on the sorption of a toxaphene model congener, the B7-1450, on marine sediments. Chemosphere 2008;71:1019-27.

15. Lai FY, Ort C, Gartner C, Carter S, Prichard $\mathrm{J}$, Kirkbride P, et al. Refining the estimation of illicit drug consumptions from wastewater analysis: Co-analysis of prescription pharmaceuticals and uncertainty assessment. Water Res 2011;45:4437-48.

16. van Nuijs ALN, Castiglioni S, Tarcomnicu I, Postigo C, de Alda ML, Neels H, et al. Illicit drug consumption estimations derived from wastewater analysis: a critical review. Sci Total Environ 2011;409: 3564-77.

17. Boleda MR, Galceran MT, Ventura F. Trace determination of cannabinoids and opiates in wastewater and surface waters by ultra-performance liquid chromatography-tandem mass spectrometry. J Chromatogr A 2007;1175:38-48.

18. McCall PJ, Swann RL, Laskowsky DA, Under SM, Vrona SA, Dishburger HJ. Estimation of the chemical mobility in the soil from liquid chromatographic retention times. Bull Environ Contam Toxicol 1980;24:190-5. 